Article

\title{
Investigation of the Prevalence, Virulence Genes, and Antibiogram of Motile Aeromonads Isolated from Nile Tilapia Fish Farms in Egypt and Assessment of their Water Quality
}

\author{
Fatma A. El-Gohary ${ }^{1, *(\mathbb{D})}$, Eman Zahran ${ }^{2} \mathbb{D}^{\mathbb{D}}$, Eman A. Abd El-Gawad ${ }^{3} \mathbb{D}$, Adel H. El-Gohary ${ }^{1} \mathbb{D}_{\text {, }}$ \\ Fatma M. Abdelhamid 4 ${ }^{(D)}$, Amany El-Mleeh ${ }^{5}$, Ehab Kotb Elmahallawy ${ }^{6,7, *}$ and \\ Mona Mohieldin Elsayed ${ }^{1}$ \\ 1 Department of Hygiene and Zoonoses, Faculty of Veterinary Medicine, Mansoura University, \\ Mansoura 35516, Egypt; adelelgohary@yahoo.com (A.H.E.-G.); dr.monamohy@yahoo.com (M.M.E.) \\ 2 Department of Internal medicine, Infectious and Fish diseases, Faculty of Veterinary Medicine, \\ Mansoura University, Mansoura 35516, Egypt; emanzahran@mans.edu.eg \\ 3 Aquatic animals diseases and management department, Faculty of Veterinary Medicine, Benha University, \\ Benha 13736, Egypt; dreman_2010@yahoo.com \\ 4 Department of Clinical Pathology, Faculty of Veterinary Medicine, Mansoura University, \\ Mansoura 35516, Egypt; fatmamostafa980@yahoo.com \\ 5 Department of Pharmacology, Faculty of Veterinary Medicine, Menoufia University, Sheibin Elkom 32511, \\ Egypt; amany.ahmed1074@gmail.com \\ 6 Department of Biomedical Sciences, University of León, 24071 León, Spain \\ 7 Department of Zoonotic diseases, Faculty of Veterinary Medicine, Sohag University, Sohag 82524, Egypt \\ * Correspondence: dr.fatmagohary@gmail.com (F.A.E.-G.); eehaa@unileon.es (E.K.E.)
}

Received: 12 July 2020; Accepted: 14 August 2020; Published: 16 August 2020

Simple Summary: Motile Aeromonas Septicemia (MAS) has been considered one of the most important bacterial diseases affecting the aquaculture industry in Egypt, and it is also a public health concern. The present study investigated the prevalence, virulence genes, and antibiogram of motile aeromonads isolated from Nile tilapia fish farms in Egypt through bacteriological, molecular, and histopathological identification. The work also involved assessment of the water quality of the examined fish farms. Our results reported Aeromonas isolates in $33.3 \%$ and $12.5 \%$ of fish and water samples, respectively, followed by their molecular identification at the genus level. The recovered motile aeromonads harbored four virulence genes: aerolysin, elastase, hemolysin, and lipase. The antibiogram profile revealed the highest resistance of aeromonads to chloramphenicol, kanamycin, and azithromycin, while lower resistance was recorded against streptomycin, cefotaxime, and amoxicillin. Likewise, severe histopathological changes were evident in liver and spleen that cohere with MAS. Taken together, our data provide interesting information in relation to the adverse impact of water quality and motile aeromonads as a repository of antimicrobial resistance and virulence genes in the aquaculture industry in Egypt.

Abstract: The aquaculture industry is a fast-growing sector in Egypt; however, the progress of this industry is impeded by many challenges such as poor water quality and associated bacterial infections. Among others, Motile Aeromonas Septicemia (MAS), caused by aeromonads, is among the most important bacterial diseases affecting aquaculture due to its zoonotic potential. In the present work, motile aeromonads were isolated from water samples $(n=8)$ and Nile tilapia $(n=240)$ in four fish farms (farms I, II, III, and IV) in Kafr El-Sheikh province during the period March to August 2017. This step was followed by investigation of the prevalence and phenotypic, molecular, and histopathological characterization of aeromonads. In addition, antimicrobial susceptibility and virulence gene detection were analyzed. Interestingly, physicochemical water analysis revealed 
different ranges in relation to the fish farms and seasons. More importantly, Aeromonas isolates were phenotypically identified in $33.3 \%$ and $12.5 \%$ from fish and water samples, respectively. The highest prevalence of motile aeromonads (46.7\%) was recorded from farm IV, and only $12.5 \%$ of water samples were positive for them. Out of 80 isolates, $65(81.25 \%)$ were molecularly identified at the genus level using gyrase B $(g y r B)$. The prevalence of the virulence genes detected in the isolated motile aeromonads was aerolysin (aer), 52.2\%; elastase (ahp), 26.25\%; hemolysin ( $h y l), 35 \%$; and lipase (lip), 3.75\%. The antibiogram profile revealed that the highest resistance of aeromonads isolates (80\%) was recorded to chloramphenicol, kanamycin, and azithromycin. Meanwhile, lower resistance levels of $40 \%, 30 \%$, and $20 \%$ were found for streptomycin, cefotaxime, and amoxicillin, respectively. The multiple antibiotic resistance (MAR) index values ranged between 0.27 and 0.82 of motile aeromonads isolates. Furthermore, the histopathological examinations of naturally diseased tilapia revealed widespread hepatocellular necrosis with diffuse, numerous rod-shaped bacteria in liver with melanomacrophages and lymphocytic depletion with edema and hemosiderosis in the spleen. Our findings provide an updated epidemiological baseline for future reference and highlight the likely role of the adverse impact of water quality in the outbreaks of motile aeromonads with special reference to virulence genes and antibiotic resistant traits.

Keywords: Aeromonas; Egypt; fish farms; physicochemical water parameters; virulence genes

\section{Introduction}

The aquaculture industry is a fast-growing sector, which supplies nearly one-third of the world's seafood requirements [1]. It also helps address unemployment problems by providing employment opportunities for the growing population [2]. Furthermore, fish constitute a significant part of protein consumption in many places all over the world. At the regional level, Egypt is considered to have one of the largest aquaculture industries in Africa, whereas this industry has grown by $45 \%$ over the past few years [3]. Therefore, it is not surprising to mention that there is an increasing concern regarding this industry in Egypt, particularly in relation to the ambitious plans of the Egyptian government to set up new aquaculture farms such as the Birkat Ghalioun fish pond project [4]. This fish pond project is considered the largest farm in the Middle East and is considered one of such plans to meet the increased population demand [4]. Among freshwater species, Nile tilapia is the most common commercially farmed fish in Egypt, supplying over $67 \%$ of total fish production [5]. This is mainly owing to their rapid growth rate, high nutritive values, and disease tolerance, promoting higher production levels [5]. With the expansion of aquaculture and due to limited water resources, fish farm intensification has been adopted along with wastewater use such as agriculture drainage water [6]. It should be stressed that wastewater effluents contain different types of xenobiotics that eventually influence the fish health and render them more susceptible to infections with huge losses [6]. Motile aeromonads are ubiquitous bacteria in the aquaculture habitat; however, under stress conditions, they might cause an important hemorrhagic septicemic disease in fish besides being associated with serious public health concerns in humans, as they cause gastroenteritis [7]. It is noteworthy to mention that molecular identification using PCR has been used for the determination of etiologic agents in several diseases, and such methods are able to identify possible genes that encode virulence factors responsible for microbial pathogenesis [8]. Sequencing the housekeeping genes such as the gyrase B $(g y r B)$ in aeromonads was documented as a reliable method for identification since the sequencing of 16S rRNA has limited resolution for closely related species [9]. Virulence factors, especially those related to extracellular products, have a crucial role in the translocation of Aeromonas spp. in the epithelium, and therefore, they are broadly associated with pathogenicity [10]. Two aeromonads were identified as A. hydrophila and A. veronii biovar sobria using the nucleotide sequence of the $g y r B$ gene along with the detection of Lipase (Lip), Aerolysin (aer), Serine protease (Ser), Cytotoxic enterotoxin $(A C T)$, and temperature-sensitive protease 
(CAI) virulence genes [11]. In another investigation, aer and hemolysin (hyl) virulence factors were detected from aeromonads isolates [12]. Taken into account, antimicrobials have been hugely used over the last decades for the prevention and control of bacterial diseases in aquaculture [13], which in turns led to the emergence of antimicrobial-resistant bacteria [14]. Given the above information, the present study was undertaken to investigate the summer prevalence of motile aeromonads in different fish farms receiving poor quality water, at Kafr-El-Sheikh province, Egypt, using phenotypic and molecular characterization together with investigation of the antibiotic resistance patterns and water quality analysis of these farms.

\section{Materials and Methods}

\subsection{Ethical Considerations}

The study protocol was reviewed and approved by the local guidance of the Research Ethics Committee of the Faculty of Veterinary Medicine, Mansoura University, Egypt.

\subsection{Study Area and Data Collection}

The present study was conducted between March and August 2017. A total number of four Nile tilapia fish farms (I, II, III, and IV) located at Kafr-Elsheikh governorate, Egypt were selected, as 55\% of the cultured fish production in Egypt is recorded from this area [15]. Fish farms were selected based on the type of fish production, water source, nearby sewage areas, chemotherapy used, and the previous history of fish mortalities in the last two summer seasons. Farm visits were done monthly to cover the whole study period. Fish farmers were interviewed and agreed orally to share in the structured questionnaire, including individual, location, and farm information (Table 1).

Table 1. The key characteristics of the examined fish farms at Kafrelshiekh province, Egypt.

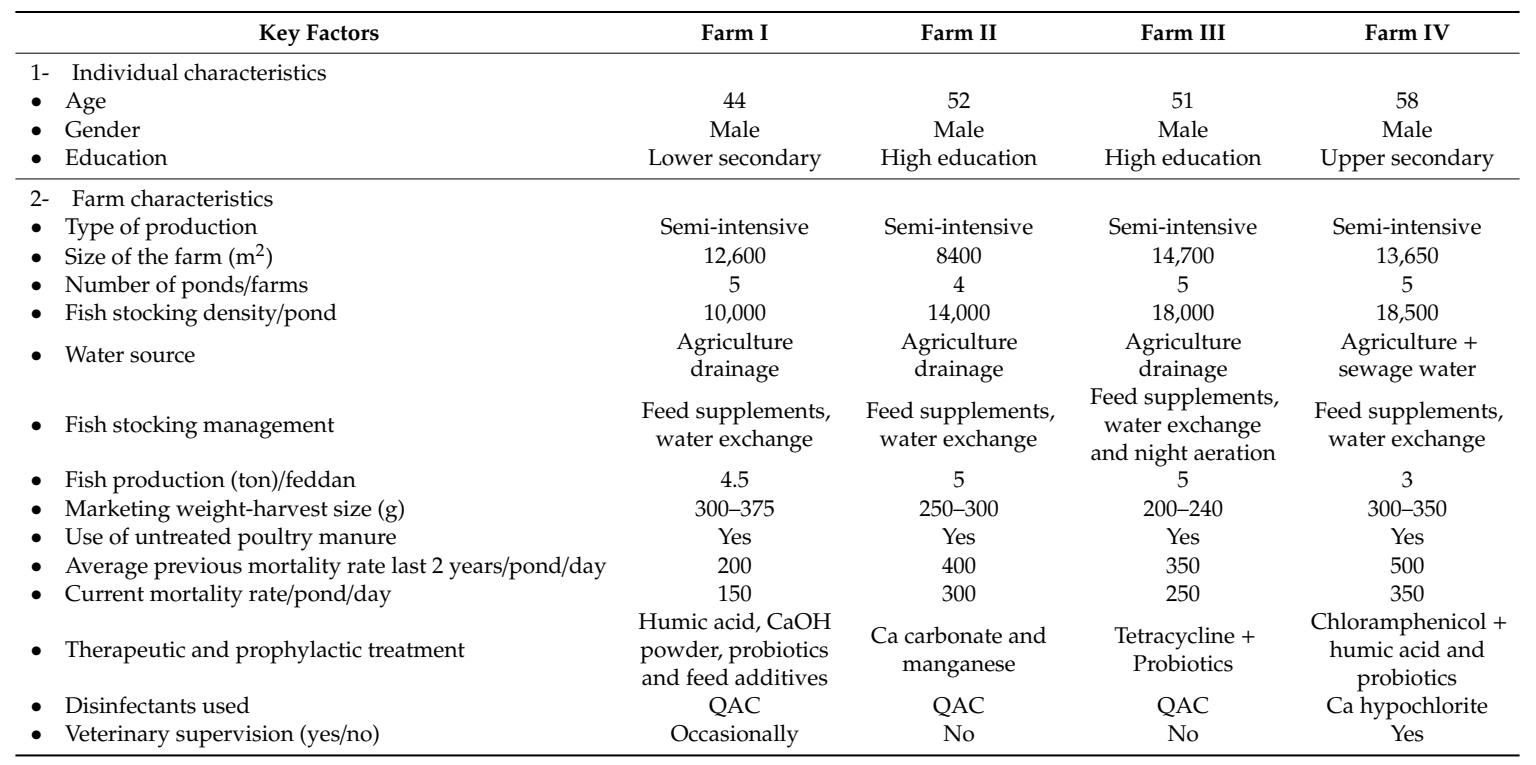

\subsection{Sampling}

Nile tilapia (Oreochromis niloticus) fish samples were collected monthly throughout the study period (March-August 2017). Two water samples were collected from each farm for the screening of water parameters, one in March and the other in August. About $100 \mathrm{~mL}$ of water sample was collected in sterile $500 \mathrm{~mL}$ glass bottles, between 10:00 and 12:00 at depth of $30 \mathrm{~cm}$ below the water surface. Each sample was labeled with the following information: number, site, date and time of collection, name of the farm owner, and type of fish production. Then, they were transported to the laboratory in an icebox and stored at $4{ }^{\circ} \mathrm{C}$ according to methods mentioned elsewhere [16]. The samples were analyzed 
within the next 1-2 $\mathrm{h}$ or kept in the refrigerator not more than $24 \mathrm{~h}$. Upon farm visits, two ponds were randomly selected; then, five fish were collected per each pond with a total of 60 fish for each farm during the whole study period. Healthy and infected fish were collected with a preference for fish showing signs of Motile Aeromonas Septicemia (MAS); then, they were transported alive in a large plastic water container provided with battery aerators as an air source to the laboratory for further investigation. Average lengths and body weights were recorded; then, the clinical examination of fish was performed [17].

\subsection{Assessment of Water Quality Parameters}

The temperature, $\mathrm{pH}$, and dissolved oxygen of water were determined in situ at the farm using a thermometer, $\mathrm{pH}$ meter, and oxygen meter (Lovibond ${ }^{\circledR}$, Dortmund, Germany). Other chemical parameters such as total dissolved solids (TDS), conductivity, nitrate, nitrite, ammonia-nitrogen, and phosphorus were measured using a multiparameter bench photometer (HANNA ${ }^{\circledR}$, HI83200-02, Schaumburg, IL, USA).

\subsection{Bacteriological Examination}

A total number of 240 fish samples at a rate of five fish/farm/month and eight water samples were collected during the study period. For bacteriological isolation from water samples, $100 \mathrm{~mL}$ was serially diluted; then, $1 \mathrm{~mL}$ of the sample was directly streaked on Oxoid ${ }^{\mathrm{TM}}$ Aeromonas Medium Base (Ryan) with Ampicillin supplement. For the detection of Aeromonas from collected tilapia, liver and kidney were sampled and investigated as previously described elsewhere [18]. All collected samples were taken under complete aseptic conditions and seeded directly onto Oxoid ${ }^{\mathrm{TM}}$ Aeromonas Medium Base (Ryan) with ampicillin supplement $2.5 \mathrm{mg} / 500 \mathrm{~mL}$ of diluted media; then, they were incubated at $28^{\circ} \mathrm{C}$ for $24-48 \mathrm{~h}$ for the isolation of Aeromonas from fish and water. Four to five small dark green convex bull eye-shaped colonies with a dark green center were picked up, purified, and biochemically identified according to the criteria described in Bergy's Manual of Determinative Bacteriology [19]. Further molecular characterization was carried out on purified biochemically identified strains kept in BHI (brain heart infusion broth) with $15 \%$ glycerol at $-20{ }^{\circ} \mathrm{C}$ [12].

\subsection{Molecular Identification of the Recovered Aeromonas Isolates}

The genomic DNA of Aeromonas isolates was extracted using a Gene jet genomic DNA purification kit (Thermo Fisher Scientific Inc., USA) according to the manufacturer's instructions. The extracted DNA was subjected to gyrB gene sequencing for the identification of Aeromonas isolates at the genus level, as mentioned elsewhere [20]. Aeromonas isolates were recognized for the presence of four virulence genes: aer, hyl, lip, and elastase (ahp) using specific primers as described elsewhere [20-22]. Aliquots from amplification reactions were analyzed by $1 \%$ agarose gel electrophoresis and viewed under UV light. The primer sets, PCR conditions, and size of the amplified sequence are shown in Table 2.

\subsection{Screening of Antimicrobial Susceptibility of Aeromonas and MAR Index}

Twenty representative Aeromonas fish isolates $(n=5 /$ farm) that showed positive results for Aeromonas virulence genes (aer, hyl, and $a h p$ ) were tested for their antimicrobial susceptibility using a Kirby-Bauer disk diffusion method against 11 commercially available antimicrobials on Mueller-Hinton agar (Oxoid, Hampshire, UK) according to the Clinical and Laboratory Standards Institute (CLSI) guidelines [23]. These 11 antibiotic discs (Oxoid, Hampshire, United Kingdom) were chloramphenicol (C; $30 \mu \mathrm{g})$, ciprofloxacin (CIP; $5 \mu \mathrm{g})$, tetracycline (TE; $5 \mu \mathrm{g})$, amoxicillin (AM; $30 \mu \mathrm{g})$, cefotaxime (CXT; $30 \mu \mathrm{g})$; kanamycin $(\mathrm{K} ; 30 \mu \mathrm{g})$; trimethoprim/ sulphamethoxazole (SXT; $25 \mu \mathrm{g})$; gentamycin (CN; $10 \mu \mathrm{g})$, azithromycin (AZM; $15 \mu \mathrm{g})$, streptomycin $(S ; 10 \mu \mathrm{g})$, and imipenem (IPM; $10 \mu \mathrm{g})$. Then, the results were evaluated as susceptible (S), intermediate (I), or resistant (R) by measuring the inhibition diameter zone following 
the guidelines of [23]. The MAR index was calculated by dividing the total number of resistances to antimicrobials by each isolate on the total numbers of tested antimicrobials [24]. The isolates that exhibited resistance to three or more classes of antimicrobials were considered as multidrug-resistant strains [25].

\subsection{Histopathological Examination of Naturally Diseased Nile Tilapia}

Tissue specimens from the liver and spleen of naturally diseased Nile tilapia were excised and fixed in $10 \%$ neutral buffered formalin for $24 \mathrm{~h}$. The fixed tissues were then processed for staining with hematoxylin and eosin (H\&E) [26]. The tissue sections were examined with a light microscope (Olympus CX41, Olympus Medical systems India Private Limited, Haryana, India) and photographed.

Table 2. The primer sets, PCR conditions, and size of the amplified sequence of Aeromonas isolates.

\begin{tabular}{|c|c|c|c|c|}
\hline Genes & Primers Sequence $\left(\left(5^{\prime}-3^{\prime}\right)\right.$ & PCR Conditions & Product Sizes/(Bp) & Reference \\
\hline Gyrase B (gyrB) & $\begin{array}{l}\text { TCCGGCGGTCTGCACGGCGT } \\
\text { TTGTCCGGGTTGTACTCGTC }\end{array}$ & $\begin{array}{l}\text { - Initial denaturation } 94^{\circ} \mathrm{C} / 5 \mathrm{~min} \text {. } \\
\text { - } 30 \text { cycles of denaturation at } 94{ }^{\circ} \mathrm{C} / 30 \mathrm{~s} \\
\text { - Annealing at } 59{ }^{\circ} \mathrm{C} / 30 \mathrm{~s} \\
\text { - Extension at } 72{ }^{\circ} \mathrm{C} / 1 \mathrm{~min}\end{array}$ & 1100 & [20] \\
\hline Aerolysin (aer) & $\begin{array}{l}\text { AACCGAACTCTCCAT } \\
\text { CGCCTTGTCCTTGTA }\end{array}$ & $\begin{array}{l}\text { - Initial denaturation step at } 94^{\circ} \mathrm{C} / 5 \mathrm{~min} \\
\text { - } 30 \text { cycles with denaturation at } 94^{\circ} \mathrm{C} / 30 \mathrm{~s} \\
\text { - Annealing at } 54^{\circ} \mathrm{C} / 30 \mathrm{~s} \\
\text { - Extension at } 722^{\circ} \mathrm{C} / 1 \mathrm{~min}\end{array}$ & 301 & [21] \\
\hline Elastase $(a h p)$ & $\begin{array}{l}\text { ACACGGTCAAGGAGATCAAC } \\
\text { CGCTGGTGTTGGCCAGCAGG }\end{array}$ & $\begin{array}{l}\text { - Initial denaturation: } 94^{\circ} \mathrm{C} / 4 \mathrm{~min} \\
\text { - } 35 \text { cycles of denaturation at } 94^{\circ} \mathrm{C} \text { for } 30 \mathrm{~s} \\
\text { - Annealing at } 55.5^{\circ} \mathrm{C} \text { for } 30 \mathrm{~s} \\
\text { - Extension step at } 72^{\circ} \mathrm{C} \text { for } 30 \mathrm{~s}\end{array}$ & 540 & [27] \\
\hline Hemolysin $(h y l)$ & $\begin{array}{l}\text { CACAGCCAATATGTCGGTGAAG } \\
\text { GTCACCTTCTCGCTCAGGC }\end{array}$ & $\begin{array}{l}\text { - Same amplification conditions for elastase } \\
\text { gene except for annealing at } 60.6^{\circ} \mathrm{C} \text { for } 30 \mathrm{~s}\end{array}$ & 326 & [22] \\
\hline Lipase (lip) & $\begin{array}{l}\text { ATCTTCTCCGACTGGTTCGG } \\
\text { CCGTGCCAGGACTGGGTCTT }\end{array}$ & $\begin{array}{l}\text { - Same amplification conditions for elastase } \\
\text { gene except for annealing at } 58.2^{\circ} \mathrm{C} \text { for } 30 \mathrm{~s}\end{array}$ & $383-389$ & [27] \\
\hline
\end{tabular}

\subsection{Statistical Analysis}

Data were analyzed using simple descriptive statistics such as frequency distribution and percentages. Prevalence of infection was calculated by using the following formula:

Prevalence of infection $(\%)=$ No. of infected fish/Total no. of examined fish

\section{Results}

\subsection{Characteristics of Fish Farms}

Farm owners willingly responded to the structured questionnaire in Table 1 . This questionnaire aimed to assess the farm status and reveal the relationship between farm characteristics and the incidence rate of Aeromonas at the genus level. The results showed that all farm owners were males of middle-age with moderate to high education levels. Upon study, all farms were of semi-intensive production type with a size ranging between 8400 and $14,700 \mathrm{~m}^{2}$ and with a stocking density between 10,000 and 18,500 fish/pond. Agriculture drainage runoff was the main water source for all fish farms, but farm IV has sewage source plus agriculture drainage. As a fish management protocol, all farms were dependent on feed supplements with water exchange, but only farm III had water paddles in addition to this management protocol. The average fish production ranged between 3 and 5 tonnes/ha with a final marketing weight that fluctuated between 200 and $375 \mathrm{~g}$, with an average of $289.4 \mathrm{~g}$ in the examined farms. All farmers used poultry manure without treatment in fish pond fertilization. The mortality rate in the previous two years was estimated by fish owners as between 200 and 500 fish/day in each pond during summer months, where the highest mortalities (500 fish) were recorded in farm IV. Meanwhile, the mortalities in the year while the study was carried out decreased to a range of 150-350 fish/day. Prophylactic and therapeutic treatments differed among the examined farms, where farm I used humic acid, $\mathrm{CaOH}$ powder, probiotics, and feed additives, while farm II used calcium carbonate and manganese. Antibiotics were used in farm III, which used tetracyclines in 
addition to probiotics, and farm IV used chloramphenicol with humic acid and probiotics. Regarding disinfectants, quaternary ammonium compounds were the most used disinfectants in all the examined farms, but farm IV used calcium hypochlorite. The owner of farm IV stated that he had veterinary supervision lately because of the high mortalities occurring in the last two years. Whereas farm I had an occasional veterinary inspection in case of outbreaks, the owners of farms II and III declared a complete absence of veterinary inspection as they depend on their own experiences and neighbors' advice from fish farmers.

\subsection{Water Quality Parameters}

Some physicochemical water quality parameters were measured in March and August 2017 in the examined fish farms, which are detailed in Table 3. All water physicochemical parameters were notably higher in August than March. At the farm level in relation to the studying period, Farm III displayed the highest levels of temperature, $\mathrm{pH}$, dissolved oxygen (DO), ammonia, nitrate, and nitrite among all examined farms in August as follows: $30.8{ }^{\circ} \mathrm{C}, 8.9,4.7 \mathrm{mg} / \mathrm{L}, 1.8 \mathrm{mg} / \mathrm{L}, 0.5 \mathrm{mg} / \mathrm{L}$, and $0.69 \mathrm{mg} / \mathrm{L}$, respectively. Meanwhile, electrical conductivity (EC), TDS, and phosphorus achieved the maximum values $3968 \mathrm{mho} / \mathrm{cm}, 1978.6 \mathrm{mg} / \mathrm{L}$, and $1.9 \mathrm{mg} / \mathrm{L}$, respectively in farm IV during August.

Table 3. Physicochemical water parameters of the examined farms at the beginning and at the end of study (March and August 2017).

\begin{tabular}{|c|c|c|c|c|c|c|c|c|c|}
\hline \multirow{2}{*}{ Parameter } & \multicolumn{2}{|c|}{ Farm I } & \multicolumn{2}{|c|}{ Farm II } & \multicolumn{2}{|c|}{ Farm III } & \multicolumn{2}{|c|}{ Farm IV } & \multirow{2}{*}{$\begin{array}{l}\text { Standard Limits } \\
\text { [Reference] }\end{array}$} \\
\hline & March & August & March & August & March & August & March & August & \\
\hline Temp. $\left({ }^{\circ} \mathrm{C}\right)$ & 23.5 & 28.9 & 21.2 & 34.1 & 23.4 & 30.8 & 24.7 & 33.8 & $28-30[28]$ \\
\hline $\mathrm{Ph}$ & 7.2 & 8.6 & 7.9 & 8.8 & 7.5 & 8.9 & 8 & 8.5 & $6.5-9$ [29] \\
\hline $\mathrm{DO}(\mathrm{mg} / \mathrm{L})$ & 3.4 & 4 & & 4.5 & 3.8 & 4.7 & 3.1 & 4 & $6-14[30]$ \\
\hline $\mathrm{EC}(\mathrm{mho} / \mathrm{cm})$ & 1588 & 2865 & 1365 & 3771 & 2547 & 3524 & 2620 & 3968 & $60-2000 \mu \mathrm{S} / \mathrm{cm}[31]$ \\
\hline TDS (mg/L) & 796 & 1524 & 674.5 & 1886 & 1281.3 & 1658.4 & 1342.1 & 1978.6 & $\leq 80[32]$ \\
\hline Ammonia (mg/L) & 1.01 & 1.42 & 0.55 & 1.62 & 1.3 & 2.6 & 1.8 & 3.4 & $0.6-2.0[33]$ \\
\hline $\mathrm{NH}_{3}-\mathrm{N}(\mathrm{mg} / \mathrm{L})$ & 0.36 & 1.17 & 0.42 & 1.05 & 0.49 & 0.98 & 0.6 & 1.23 & $<0.05-1.0[29]$ \\
\hline Nitrate $(\mathrm{mg} / \mathrm{L})$ & 0 & 0 & 0 & 0.3 & 0.2 & 0.5 & 0 & 0.4 & $<3$ [33] \\
\hline Nitrite (mg/L) & 0.1 & 0.31 & 0.1 & 0.34 & 0.21 & 0.69 & 0.07 & 0.23 & $<0.5[34]$ \\
\hline Phosphorus (mg/L) & 1.17 & 1.46 & 0.69 & 0.92 & 0.58 & 0.78 & 1.87 & 1.9 & $0.05-0.5[31]$ \\
\hline
\end{tabular}

$\mathrm{DO}=$ dissolved oxygen, $\mathrm{EC}=$ electrical conductivity, TDS = total dissolved solids.

\subsection{Fish Examination}

The selection of the study period was based mainly on the previous history of outbreaks and mortalities that were encountered during the summer. A total number of 60 fish samples were collected from each farm throughout the study period with slight differences between healthy and infected fish numbers from each farm, depending on the availability of infected fish on each visit. The ranges of lengths and weights were 7.85-16.71 cm and 16.35-196.85 g, respectively (Table S1). Alongside farm visits, fish mortalities were noticed at the water surface and on the banks of fish ponds, where farmers just picked up dead fish and threw them on the banks (Figure S1). A variety of clinical signs were observed on dead fish upon examination, including hemorrhages on the skin and fins, vent opening, detached scales with deep skin ulceration, fin erosions, distended abdomen, and exophthalmia (Figure S2).

\subsection{Bacteriological and Phenotypic Characterization}

Upon bacteriological examination, typical Aeromonas colonies were picked up and biochemically examined. The obtained bacterial isolates were Gram-negative, motile bacilli, oxidase, catalase, and aesculin hydrolysis-positive with the ability to ferment glucose with acid and gas production. Biochemical results revealed that Aeromonas spp. was recovered from only one water sample (12.5\%) and 80 fish samples (33.3\%) among the examined samples (Table S2). 


\subsection{Total and Monthly Prevalence of Aeromonas}

The total prevalence of motile aeromonads recovered from fish samples was 46.7\%, 33.3\%, 28.3\%, and $25 \%$ from farms IV, III, II, and I, respectively (Table 4); whereas the prevalence of motile aeromonads in farm IV was the highest in August, July, and June, (80\%, 60\%, and 40\%, respectively). Meanwhile, only one water sample (12.5\%) was positive for motile aeromonads in farm IV (Table 5).

Table 4. Total prevalence of motile Aeromonads recovered from water and fish samples throughout the study period in the examined farms.

\begin{tabular}{ccccccc}
\hline \multirow{2}{*}{ Farms } & \multicolumn{2}{c}{ Water } & \multicolumn{2}{c}{ Fish } & \multicolumn{2}{c}{ Total Examined Samples } \\
\cline { 2 - 7 } & No. of Positive & $\mathbf{\%}$ & No. of Positive & $\mathbf{\%}$ & No. of Positive & $\mathbf{\%}$ \\
\hline I & 0 & 0 & 15 & 25 & 15 & 24.2 \\
II & 0 & 0 & 20 & 33.3 & 20 & 32.3 \\
III & 0 & 0 & 17 & 28.3 & 17 & 27.4 \\
IV & 1 & 50 & 28 & 46.7 & 29 & 46.8 \\
\hline Total & 1 & 12.5 & 80 & 33.3 & 82 & 33.1 \\
\hline
\end{tabular}

Number of samples; water $=2 /$ farm, fish $=60 /$ farm.

Table 5. Monthly prevalence of motile Aeromonads isolated from fish samples in the examined farms.

\begin{tabular}{ccccc}
\hline Months & Farm I & Farm II & Farm III & Farm IV \\
\hline March & 10 & 0 & 10 & 20 \\
April & 10 & 20 & 30 & 40 \\
May & 20 & 20 & 10 & 40 \\
June & 30 & 50 & 20 & 40 \\
July & 40 & 50 & 60 & 60 \\
August & 40 & 40 & 40 & 80 \\
\hline Total & 25 & 33.3 & 28.3 & 46.7 \\
\hline
\end{tabular}

\subsection{Molecular Identification of Aeromonads}

Molecular identification was carried out for 80 fish isolates ( $n=20 /$ farm). PCR amplification of gyrB showed that 65 isolates (81.25\%) were positively amplified at $1100 \mathrm{bp}$ (Figure S3). Virulence genes detection revealed that out of the 80 isolates, 42,21 , and 28 motile aeromonads $(52.2 \%, 26.25 \%$, and $35 \%$ ) harbored aer, ahp, and hyl genes, respectively. Meanwhile, lip gene positive isolates were lower and reached only three positive isolates (3.75\%) (Table 6).

Table 6. Molecular characterization of motile Aeromonads isolates and their virulence genes.

\begin{tabular}{ccc}
\hline Genes & No. of Positive & $\mathbf{( \% )}$ \\
\hline Gyrase B $($ gyrB) & $65 / 80$ & $(81.25)$ \\
\hline Aerolysin $($ aer $)$ & $42 / 80$ & $(52.5)$ \\
\hline Elastase $($ ahp $)$ & $21 / 80$ & $(26.25)$ \\
\hline Hemolysin $($ hyl $)$ & $28 / 80$ & $(35)$ \\
\hline Lipase $($ lip $)$ & $3 / 80$ & $(3.75)$ \\
\hline
\end{tabular}

\subsection{Antibiotic Resistance Patterns of Motile Aeromonads}

The antibiogram profile of the 20-representative typical Aeromonas isolates (5/farm) against 11 antimicrobials is presented in Table 7. Our findings revealed that Aeromonas spp. were highly resistant $(80 \%)$ to chloramphenicol, kanamycin, and azithromycin, followed by $75 \%$ of the isolates exhibiting 
resistance to trimethoprim-sulphamethoxazole. About 70\% of Aeromonas isolates showed resistance to both ciprofloxacin and gentamycin, and 65\% displayed resistance to tetracycline. Approximately, $70 \%$ of Aeromonas isolates had resistance to ciprofloxacin, and $65 \%$ were tolerant to both gentamycin and tetracycline. Lower resistance levels of 40\%, 30\%, and 20\% were observed among examined isolates to streptomycin, cefotaxime, and amoxicillin, respectively. However, only two isolates (10\%) were resistant to imipenem. According to the obtained results of antimicrobial testing, a multiple antimicrobial resistance (MAR) index was determined. Table 7 showed that the multidrug resistance pattern of Aeromonas isolates and MAR index values ranged between 0.27 and 0.82 .

Table 7. Number and percentage of Aeromonas isolates resistant to the antibiotics and multiple antibiotic resistances (MAR) index of Aeromonas isolates.

\begin{tabular}{|c|c|c|c|c|c|c|c|}
\hline \multicolumn{2}{|c|}{ Antimicrobial Resistance Pattern } & \multicolumn{6}{|c|}{ The Multiple Antibiotic Resistance (MAR) Index } \\
\hline Antibiotics & $\begin{array}{c}\text { Number of Resistant } \\
\text { Aeromonas Isolates } \\
\text { (\%) }\end{array}$ & $\begin{array}{l}\text { Isolate } \\
\text { Number }\end{array}$ & $\begin{array}{c}\text { Antibiotic } \\
\text { Resistance Profile * }\end{array}$ & MAR ** & $\begin{array}{l}\text { Isolate } \\
\text { Number }\end{array}$ & $\begin{array}{c}\text { Antibiotic } \\
\text { Resistance Profile * }\end{array}$ & MAR ** \\
\hline Ciprofloxacin (CIP) & $14(70 \%)$ & 2 & $\begin{array}{l}\text { C, CIP, TE, CXT, K, } \\
\text { SXT, CN, AZM, S }\end{array}$ & 0.82 & 36 & $\begin{array}{c}\text { C, CIP, TE, K, SXT, } \\
\text { AZM }\end{array}$ & 0.55 \\
\hline Amoxicillin (AM) & $4(20 \%)$ & 13 & $\begin{array}{l}\text { C, CIP, TE, CXT, K, } \\
\text { SXT, CN, AZM, S }\end{array}$ & 0.82 & 39 & $\begin{array}{c}\text { C, AM, CXT, K, SXT, } \\
\text { CN, AZM }\end{array}$ & 0.64 \\
\hline Cefotaxime (CXT) & $6(30 \%)$ & 23 & $\begin{array}{l}\text { C, CIP, TE, K, CN, } \\
\text { AZM, S, IPM }\end{array}$ & 0.73 & 40 & C, SXT, CN, S & 0.36 \\
\hline Kanamycin (K) & $16(80 \%)$ & 25 & $\begin{array}{c}\text { CIP, TE, K, SXT, CN, } \\
\text { AZM }\end{array}$ & 0.55 & 43 & C, CIP, K, SXT & 0.36 \\
\hline Azithromycin (AZM) & $16(80 \%)$ & 33 & $\begin{array}{c}\text { C, CIP, CXT, K, SXT, } \\
\text { CN, AZM, S }\end{array}$ & 0.73 & 48 & C, TE, SXT & 0.27 \\
\hline Streptomycin (S) & $8(40 \%)$ & 34 & $\begin{array}{l}\text { C, CIP, TE, K, SXT, } \\
\text { CN, AZM, S }\end{array}$ & 0.73 & & & \\
\hline Imipenem (IPM) & $2(10 \%)$ & & & & & & \\
\hline
\end{tabular}

* Chloramphenicol (C; $30 \mu \mathrm{g})$, Ciprofloxacin (CIP; $5 \mu \mathrm{g})$, Tetracycline (TE; $5 \mu \mathrm{g})$, Amoxicillin (AM; $25 \mu \mathrm{g})$, Cefotaxime (CXT; $30 \mu \mathrm{g})$, Kanamycin (K; $30 \mu \mathrm{g})$, Trimethoprim/sulphamethoxazole (SXT; $25 \mu \mathrm{g})$, Gentamycin (CN; $10 \mu \mathrm{g})$, Azithromycin (AZM; $15 \mu \mathrm{g})$, Streptomycin $(S ; 10 \mu \mathrm{g})$, Imipenem (IPM; $10 \mu \mathrm{g}) .{ }^{* *}$ MAR= Multiple antibiotic resistance.

\subsection{Tissue Histopathology}

As shown in Figure 1, the liver of the infected tilapia fish showed widespread hepatocellular necrosis with diffuse, numerous rod-shaped bacteria. Additionally, hepatopancreatitis with edema and widely separated lytic hepatocytes were observed (Figure 1). Lysis of the hepatopancreas and focal aggregations of inflammatory cells were evident as well (Figure 1). The spleen showed an activation of melanomacrophages with lymphocytic depletion. Furthermore, congested blood vessels with edema, widely separated splenic cells, and hemosiderosis were recorded (Figure 2). 

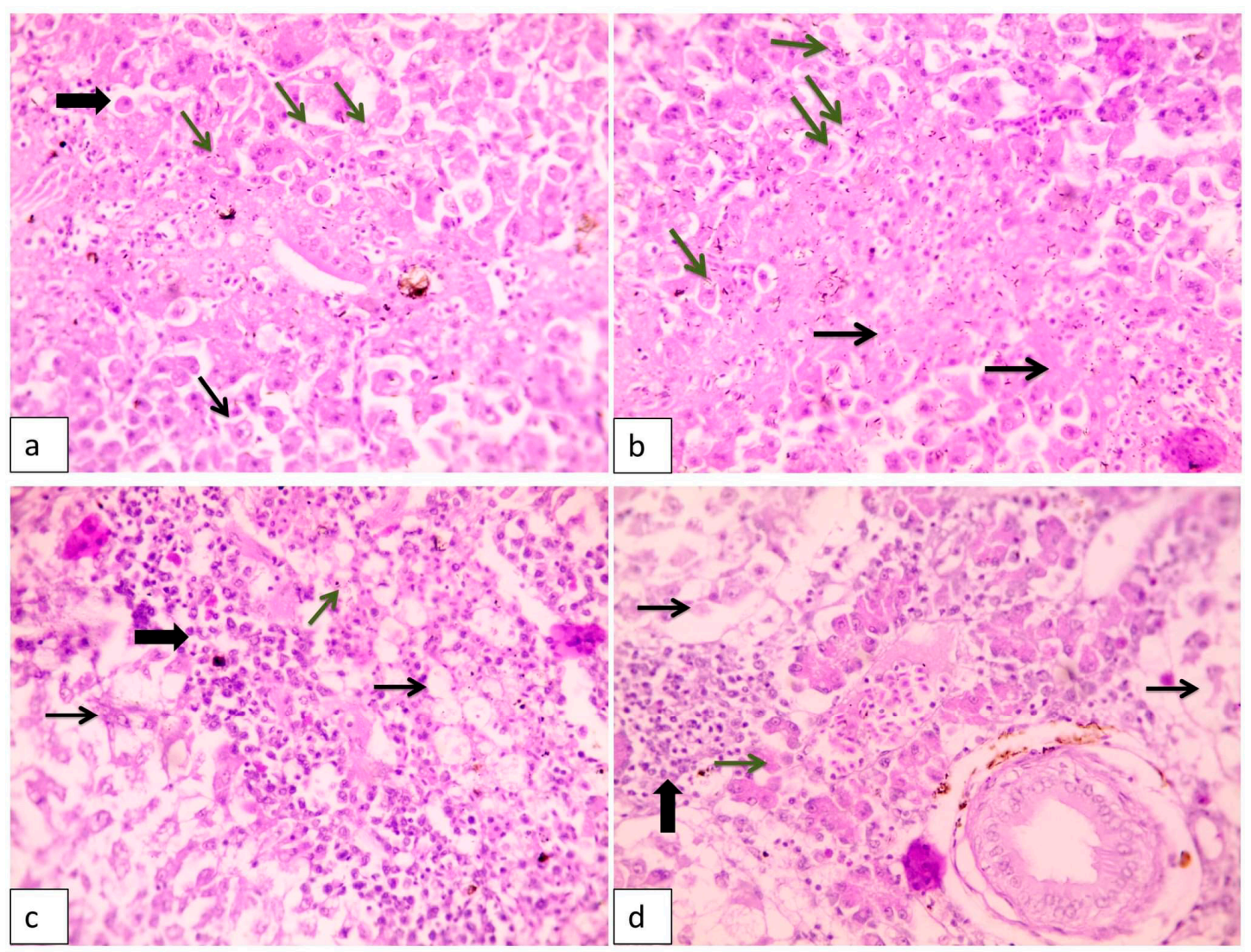

Figure 1. Histopathological lesions in liver of naturally diseased Nile tilapia showing (a) hepatocellular dissociation (thin arrow) with many necrotic and apoptotic cells (thick arrow). Few rod-shaped bacteria are inside a hepatocyte cytoplasmic vacuole (green arrows). H\&E (hematoxylin and eosin), 400×; (b) Widespread hepatocellular necrosis (black arrows) with diffuse, numerous rod-shaped bacteria (green arrows). H\&E, 400×; (c) Diffuse, severe necrotizing hepatitis. See widespread, severe hepatocellular lysis (arrows) with few bacteria (green arrow) and widespread infiltrations with numerous macrophages and lymphocytes (thick arrow). H\&E, 400x; (d) Hepatopancreatitis with edema widely separated lytic hepatocytes (arrows) and lysis of hepatopancreas (green arrow) and focal aggregations of inflammatory cells (thick arrow).
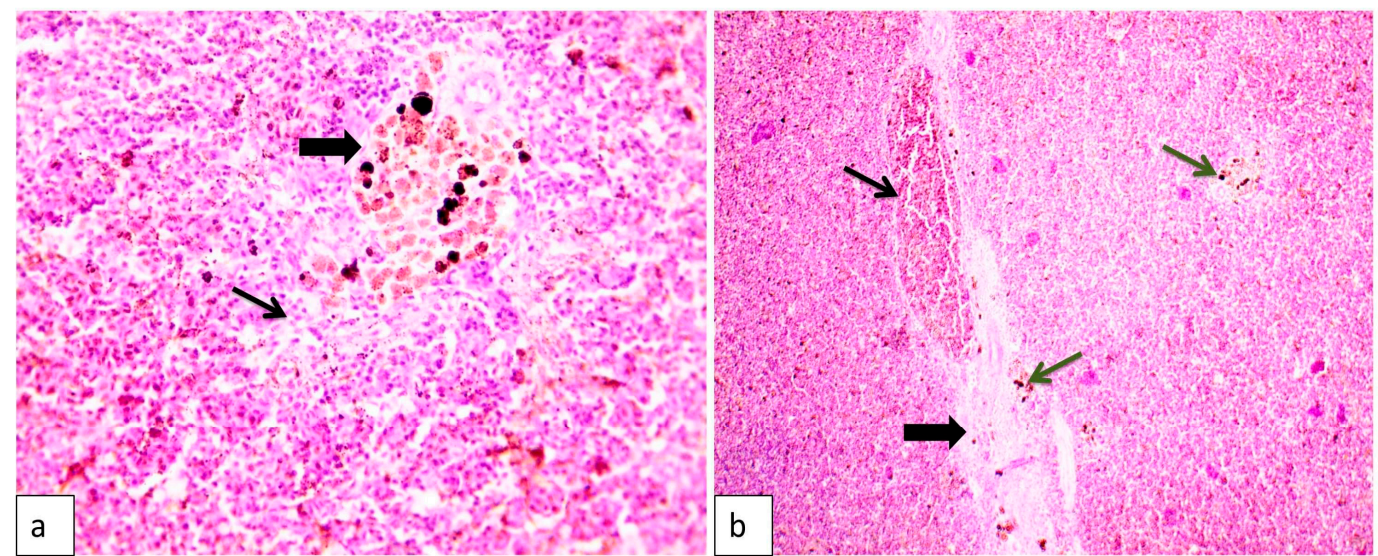

Figure 2. Histopathological lesions in spleen of naturally diseased Nile tilapia showing (a) Activation of melanomacrophages (thick arrow) with lymphocytic depletion (arrow), H\&E, 400×. (b) Congested blood vessels (thin arrow) with edema widely separated splenic cells (thick arrow) and hemosiderosis (green arrows), H\&E, 100×. 


\section{Discussion}

The present study provides interesting information relating to summer prevalence, virulence genes, and the antibiogram of motile aeromonads in Nile tilapia fish farms in Egypt. The work also involved water quality assessment in these fish farms together with some histopathological changes that reveal motile aeromonads from fish and water. It is noteworthy to state that water quality is the principal element influencing the aquaculture industry; however, most of the aquaculture sector is carried out as a run-through system with no recirculation of water or effluent treatment prior to its disposal [35]. In the current study, all farms had agriculture drainage canals as water sources except for farm IV, which received additional sewage sources. Such water resources with poor quality from agriculture drainage containing pesticides, and heavy metal pollutants have a potential impact on fish health and disease occurrence. According to the Egyptian legislation (Law No. 124/1983), only irrigation and agriculture drainage water are allowed for fish culturing [6]. Untreated poultry manure was used in all examined farms, which represents a potential health hazard for fish health [36]. As shown in our data, fish mortalities were recorded (200-500 fish/day/pond) in the last two years, especially during summer, which could be attributed to poor water quality and the usage of untreated poultry manure. Poor water quality together with poor management practices might represent a stress factors for cultured fish and thus make them more susceptible to disease outbreaks [37]. However, mortalities dropped to (150-350 fish/day/pond) during the investigation period (March-August 2017) that might be attributed to the use of antibiotics such as tetracyclines and chloramphenicol and the presence of veterinary supervision mainly in farm IV. The physicochemical parameters of water samples from the examined fish farms revealed that some of these evaluated parameters were unsuitable for tilapia culturing according to Egyptian Law standards No. 9/2009, reflecting a relatively poor-quality water source in the farms. As observed in our study, most of the measured water quality parameters, particularly at both farms III and IV (Table 2), highly fluctuated from the normal tolerable range for Tilapia as reported in previous studies [38,39]. These observations might be attributed to the usage of agriculture drainage and wastewater as the primary water sources of fish farms III and IV, respectively. As previously mentioned, such types of water are heavily loaded with pollutants such as pesticides, heavy metals, and xenosteroids runoff [40], which worsen the water quality and bioaccumulate in fish tissues. Furthermore, these abiotic stressors affect the overall fish health [41,42], rendering them susceptible to infectious diseases with subsequent economic losses [43].

Bacterial diseases are one of the many challenges facing aquaculture development [44]. Among others, motile Aeromonas septicemia (MAS), caused by Aeromonas spp., is one of such important bacterial infections, leading to fish mass mortalities and substantial economic losses $[17,45,46]$. Our results of clinical signs and postmortem lesions on affected fish coincided with previous studies reported elsewhere [47-50].

In the current results, the bacteriological isolation and biochemical identification of motile aeromonads showed that 80 out of 240 fish samples (33.3\%) and one out of eight water samples (12.5\%) were positive for motile aeromonads. Our findings are slightly higher to that reported in a previous study in New Zealand where Aeromonas were recovered at a rate of 28\% [51]; and they are nearly similar to [52], who isolated it at a rate of 26.4\% (28/132). As shown in our results, the prevalence of Aeromonas was $(46.7 \%, 33.3 \%, 28.3 \%$, and 25\%) from farms IV, III, II, and I, respectively, whereas the highest monthly prevalence rate was recorded during summer (August, June, and July) as (80\%, 60\%, and $40 \%$, respectively). These findings are related to the poor water quality parameters evaluated in the examined farms, as the highest aeromonads prevalence was noticed in farm IV and farm III, particularly in August and June. These present findings are consistent with other studies reported elsewhere [50,53]. Taken into account, the highest prevalence of Aeromonas during summer could be attributed to improper water quality parameters as measured herein, where shifting from normal ranges poses stress on fish with subsequent lowering in their resistance to bacterial infections [50,54].

Antibiotic usage in fish farms is widespread either for the prevention or treatment of bacterial infections in fish [55]; however, their indiscriminate use has led to the emergence of bacterial species 
with multiple drug resistance all over the world. Our data revealed that the majority of Aeromonas isolates showed high resistance rates against the tested antimicrobials, where most of the strains had resistance to at least 4 out of 11 evaluated antibiotics. However, few antibiotics are approved by the Food and Drug Administration (FDA), and the present observations indicate that other non-approved antibiotics tested herein were based on our questionnaire to confirm their illegal usage in some fish farms. This indiscriminate and continued use of antibiotics influences fish health, and it is also considered a public health risk [56]. In line with our results, a previous study reported a high resistance rate of $72 \%$ among Aeromonas isolates to tetracycline [57]. Furthermore, a higher resistance of up to $100 \%$ was described to tetracycline [58]. Conversely, another previous study reported that $100 \%$ of $A$. hydrophila isolates showed susceptibility to tetracycline [59]. Our results revealed a high resistance rate among examined isolates up to $75 \%$ to trimethoprim-sulphamethoxazole. These findings are higher than those reported in a previous study [60], which recorded 50\% resistance of $A$. hydrophila toward this antimicrobial agent. Meanwhile, the same antimicrobial recorded $100 \%$ sensitivity of $A$. hydrophila isolates [59]. The resistance rates of our Aeromonas isolates to kanamycin reach up to $80 \%$; meanwhile, high sensitivity rates of $28.5 \%$ and $87.5 \%$ to this antimicrobial were reported elsewhere [60,61]. Interestingly, our Aeromonas isolates showed a high resistance rate, up to $80 \%$, to ciprofloxacin, which is contrary to other studies that described ciprofloxacin as the most effective drug against Aeromonas infections [58,60,62]. However, a previous study reported 48\% resistance of Aeromonas isolates to ciprofloxacin [57]. Our study declared that streptomycin, cefotaxime, amoxicillin, and imipenem were the most active drugs against Aeromonas isolates. Other studies reported imipenem, chloramphenicol, norfloxacin, and streptomycin as the most highly effective drugs on Aeromonas [57,60,63,64].

Studying the antibiogram profiles helps in the forecasting of antibiotic resistance trends. It is obvious that these profiles differ between various studies, which could be accounted for strain-specific traits and selective environmental pressures [65]. Our findings reflect high resistance levels of Aeromonas to antimicrobials, which could be attributed to the vast use of antibiotics either as growth promoters or therapeutic agents for various diseases. A MAR index of our isolates showed high ranges between 0.27 and 0.82. In the same context, MAR index ranges of 0.25-0.68 [66] and 0.16-0.42 [50] were recorded in different Aeromonas spp. isolated from various aquatic sources.

Virulence genes are the key features in pathogenicity assessments of the microbes, and they can synergistically function $[8,67]$. Hemolysin and aerolysin are implicated in adhesins, hemagglutinins, and several hydrolytic enzymes that have a crucial role in the pathogenesis of Aeromonas spp. [68,69]. As observed in this study, the aer gene was detected in a higher number of isolates (it was detected in 42 out of 80 ), with a percentage of $52.2 \%$. Other virulence genes, including $a h p$ and hyl, were identified in lower rates as $26.25 \%$ and $35 \%$, respectively. Meanwhile, the only lip exhibited very lower detection as $3.75 \%$. Our findings support that this species has a larger matrix of virulence genes in comparison with other species of clinical relevance [70]. Moreover, the existence of more than one virulence factor could share in the pathogenicity of $A$. hydrophila that represents a possible public health risk [71]. Previous studies reported that virulence genes, including aer gene, are essential factors in Aeromonas spp. [72,73]. The existence of these virulence genes determines the pathogenicity of the infecting microorganisms and seems responsible for specific signs or diseases [72,73]. All Aeromonas strains isolated from diseased fish were identified to be virulent, even if they were deficient in one or two virulence genes [74]. Consistently, a previous study demonstrated higher prevalence rates of $81.8 \%, 88 \%$, and $100 \%$ for aer gene in isolates of Aeromonas spp. [75-77]. Furthermore, Aeromonas spp. were reported for the presence of $h l y$ genes (50\%) in fish farms in East Delta [76]. Several previous reports revealed that the genes encoding ahp and lip were identified in A. hydrophila isolates and are commonly found in isolates of Aeromonas spp. [27]. The Lip gene was found in Aeromonas isolates at 17.14\% [78], while it was highly detected (81.8\%) in A. hydrophila strains recovered from diseased Nile tilapia [79]. Meanwhile, some previous studies reported that $100 \%$ of $A$. hydrophila possess hyl and lip genes $[60,64,80]$.

In accordance with histopathological changes, as observed in the current study, liver showed different histopathological lesions in the form of widespread hepatocellular necrosis with diffuse, 
numerous rod-shaped bacteria, hepatopancreatitis, and lysis of the hepatopancreas along with focal aggregations of inflammatory cells. Spleen also showed an activation of melanomacrophages with lymphocytic depletion congested blood vessels. Our findings were consistent with previous studies that showed similar histopathological lesions due to MAS [81-83]. These observations were supportive to the motile aeromonads virulence genes herein, as well as the extracellular products, enzymes, and enterotoxins produced by motile aeromonads that together led to a systemic damage to the internal organs, mainly, liver, kidney and spleen with eventual death [9,50,67,81].

\section{Conclusions}

Taken together, the present study provides interesting data with respect to the summer mortality outbreaks in fish from Egypt due to one of the most important etiologies represented by motile aeromonads. Our data also reveal that types of legal and illegal water resources used to fill farms highlighted their crucial role in disease occurrence. Given the above information, these findings could be used as an epidemiological baseline for future references. Our study suggests that further, new strict legislations to use good water for aquaculture must be adopted, along with the monitoring of antibiotic usage and fish farm management.

Supplementary Materials: The following are available online at http://www.mdpi.com/2076-2615/10/8/1432/s1, Figure S1: Fish mortalities on water surface and on the pond banks. Figure S2: Clinical signs of freshly dead $O$. niloticus fish; hemorrhages on the skin, fins and vent opening, loosened scales with deep skin ulceration and fin erosions, distended abdomen and exophthalmia. Figure S3: Agarose gel electrophoresis of Aeromonas isolates from different sources using 100-bp molecular standard size ladder. Table S1: The number, ranges of lengths, and weights of collected tilapia fish during the study period (March-August 2017). Table S2: Phenotypic characterization results of Aeromonas species retrieved from water and fish samples in the examined fish farms.

Author Contributions: F.A.E.-G., E.Z., A.H.E.-G., F.M.A. and M.M.E. involved in the conception of the idea, methodology design, performed data analysis and interpretation. A.E.-M., E.A.A.E.-G., and E.K.E. participated in the design of the methodology, sampling, and the laboratory work and data analysis. F.A.E.-G., E.Z., and E.K.E. contributed their scientific advice, prepared the manuscript for publication and revision. All authors read and approved the final manuscript.

Funding: This research work was funded by the Research Institute Unit, Competitive projects funding Unit, Mansoura University.

Acknowledgments: The authors also thank the farm owners for their support and help in providing data and samples collection throughout the study, we also thank Huff G.R. (Poultry Production and Product Safety Research Unit, USDA, Agricultural Research Service, Poultry Science Center, University of Arkansas, Fayetteville 72701) for English-editing of our manuscript.

Conflicts of Interest: The authors declare no conflict of interest.

\section{References}

1. Subasinghe, R.; Soto, D.; Jia, J. Global aquaculture and its role in sustainable development. Rev. Aquac. 2009, 1, 2-9. [CrossRef]

2. Ottinger, M.; Clauss, K.; Kuenzer, C. Aquaculture: Relevance, distribution, impacts and spatial assessments-A review. Ocean. Coast. Manag. 2016, 119, 244-266. [CrossRef]

3. Wally, A. The State and Development of Aquaculture in Egypt. Global Agricultural Information Network. USDA Foreign Agriculture Service, 2016. Available online: https: //apps.fas.usda.gov/newgainapi/api/report/downloadreportbyfilename?filename=The $\% 20$ State $\% 20$ and $\%$ 20Development\%20of\%20Aquaculture\%20in\%20Egypt\%20_Cairo_Egypt_11-6-2016.pdf (accessed on 19 June 2020).

4. Feidi, I. Will the new large-scale aquaculture projects make Egypt self sufficient in fish supplies? Mediterranean Fish. Aquac. Res. 2018, 1, 31-41.

5. GAFRD. General authority for fish resources development. In Fish Statistics Year Book; Ministry of Agriculture and Land Reclamation: Cairo, Egypt, 2014. 
6. Naziri, D. Financial Services for Sme (Small and Medium-Scale Enterprise) Aquaculture Producers; Egypt Case Study. Draft—Confidential, 25 January 2011, German Agency for Technical Cooperation (GTZ); Natural Resources Institute: Kent, UK, 2011.

7. Figueras, M.J.; Beaz-Hidalgo, R. Aeromonas infections in humans. In Aeromonas; Caister Academic Press: Norfolk, UK, 2015; pp. 65-108.

8. Oliveira, S.T.; Gouveia, J.J.; Da Costa, M.M. Molecular characterization of virulence factors in Aeromonas hydrophila obtained from fish. Pesqui. Vet. Bras. 2012, 32, 701-706. [CrossRef]

9. Beaz-Hidalgo, R.; Figueras, M.J. Aeromonas spp. whole genomes and virulence factors implicated in fish disease. J. Fish. Dis. 2013, 36, 371-388. [CrossRef]

10. Jutfelt, F.; Sundh, H.; Glette, J.; Mellander, L.; Björnsson, B.T.; Sundell, K. The involvement of Aeromonas salmonicida virulence factors in bacterial translocation across the rainbow trout, Oncorhynchus mykiss (Walbaum), intestine. J. Fish. Dis. 2008, 31, 141-151. [CrossRef]

11. Abu-Elala, N.; Abdelsalam, M.; Marouf, S.; Setta, A. Comparative analysis of virulence genes, antibiotic resistance and gyrb-based phylogeny of motile aeromonas species isolates from Nile Tilapia and domestic fowl. Lett. Appl. Microbiol. 2015, 5, 429-436. [CrossRef]

12. Yogananth, N.; Bhakyaraj, R.; Chanthuru, A.; Anbalagan, T.; Nila, K.M. Detection of virulence gene in aeromonas hydrophila isolated from fish samples using pcr technique. Glob. J. Biotech. Biochem. 2009, 4, 51-53.

13. Hossain, S.; De Silva, B.C.J.; Wimalasena, S.H.M.P.; Pathirana, H.N.K.S.; Dahanayake, P.S.; Heo, G.J. Distribution of antimicrobial resistance genes and class 1 integron gene cassette arrays in motile Aeromonas spp. isolated from goldfish (Carassius auratus). Microb. Drug Resist. 2018, 8, 1217-1225. [CrossRef]

14. Dobiasova, H.; Kutilova, I.; Piačková, V.; Veselý, T.; Cizek, A.; Dolejska, M. Ornamental fish as a source of plasmid-mediated quinolone resistance genes and antibiotic resistance plasmids. Veter. Microbiol. 2014, 171, 413-421. [CrossRef]

15. Macfadyen, G.; Allah, A.N.; Kenawy, D.A.R.; Ahmed, M.; Hebicha, H.; Diab, A.; Hussein, S.; Abouzied, R.; Naggar, G.E. Value-Chain Analysis of Egyptian Aquaculture; Project Report 2011-54; The WorldFish Center: Penang, Malaysia, 2012; 84p.

16. Boyd, C.E.; Tucker, C.S. Pond Aquaculture Water Quality Management; Springer Science and Business Media LLC, Springer: Manhattan, New York City, NY, USA; Available online: https://www.mobt3ath.com/uplode/ book/book-23387.pdf (accessed on 15 June 2020).

17. Noga, E.J. Fish Disease: Diagnosis and Treatment; John Wiley and Sons: Hoboken, NJ, USA, 2010; Available online: https://www.wiley.com/en-us/Fish+Disease \%3A+Diagnosis+and+Treatment\%2C+2nd+Edition-p9780813806976 (accessed on 10 July 2020).

18. Buller, N.B. Bacteria from Fish and Other Aquatic Animals: A Practical Identification Manual; Cabi: Wallingford, Oxfordshire, England, 2004.

19. Holt, J.; Krieg, N.; Sneath, P.; Staley, J. Bergey's Manual of Determinative Bacteriology, 9th ed.; Lippincott Williams \& Wilkins: Baltimore, MD, USA, 1994.

20. Yáñez, M.A.; Catalan, V.; Apráiz, D.; Figueras, M.J.; Martínez-Murcia, A. Phylogenetic analysis of members of the genus Aeromonas based on gyrB gene sequences. Int. J. Syst. Evol. Microbiol. 2003, 53, 875-883. [CrossRef] [PubMed]

21. Sen, K.; Rodgers, M. Distribution of six virulence factors in Aeromonas species isolated from US drinking water utilities: A PCR identification. J. Appl. Microbiol. 2004, 97, 1077-1086. [CrossRef] [PubMed]

22. Dahdouh, B.; Basha, O.; Khalil, S.; Tanekhy, M. Molecular characterization, antimicrobial susceptibility and salt tolerance of aeromonas hydrophila from fresh, brackish and marine fishes. Alex. J. Veter. Sci. 2016, 48, 46-53. [CrossRef]

23. CLSI. Performance Standards for Antimicrobial Susceptibility Testing of Bacteria Isolated from Aquatic Animals; Second Informational Supplement; Clinical and Laboratory Standards Institute: Pittsburgh, PA, USA, 2014.

24. Krumperman, P.H. Multiple antibiotic resistance indexing of Escherichia coli to identify high-risk sources of fecal contamination of foods. Appl. Environ. Microbiol. 1983, 46, 165-170. [CrossRef]

25. Schwarz, S.; Silley, P.; Simjee, S.; Woodford, N.; van Duijkeren, E.; Johnson, A.P.; Gaastra, W. Assessing the antimicrobial susceptibility of bacteria obtained from animals. J. Antimicrob. Chemother. 2010, 4, 601-604. [CrossRef] 
26. Bancroft, J.D.; Gamble, M. Theory and Practice of Histological Techniques, 6th ed.; Churchill Livingstone: Edinburgh, UK, 2008.

27. Sen, K. Development of a rapid identification method for Aeromonas species by multiplex-PCR. Can. J. Microbiol. 2005, 51, 957-966. [CrossRef]

28. Petit, J. Water supply, treatment, and re-cycling in aquaculture. In Aquaculture; Bamabe, G., Ed.; Ellis Horwood: New York, NY, USA, 1990; Volume 1.

29. Lawson, T.B. Water quality and environmental requirements. In Fundamentals of Aquacultural Engineering; Springer: Boston, MA, USA, 1995; pp. 12-39.

30. Zweig, R.D.; Morton, J.D.; Stewart, M.M. Source Water Quality for Aquaculture; World Bank: Washington, DC, USA, 1999.

31. Stone, N.M.; Shelton, J.L.; Haggard, B.E.; Thomforde, H.K. Interpretation of Water Analysis Reports for Fish Culture; Southern Regional Aquaculture Center: Beltsville, MD, USA, 2013.

32. Boyd, C.E. Water quality for pond aquaculture. Res. Dev. 1998, 43, 1-11.

33. Meade, J.W. Aquaculture Management; Springer Science and Business Media LLC: Berlin, Germany, 1989.

34. Swann, L. Water Quality Water Sources Used in Aquaculture. Water Quality Fact Sheet as-486. Aquaculture Extension; Illinois-Indiana Sea Grant Program; Purdue University: West Lafayette, IN, USA, 1993.

35. Agoz, H.; Abbas, H.; Mahmoud, H. Rice-fish-azolla integrated culture systems. Egypt. J. Aquat. Biol. Fish. 2005, 2, 65-85.

36. Sapkota, A.; Sapkota, A.R.; Kucharski, M.; Burke, J.; McKenzie, S.; Walker, P.; Lawrence, R. Aquaculture practices and potential human health risks: Current knowledge and future priorities. Environ. Int. 2008, 34, 1215-1226. [CrossRef]

37. Zamri-Saad, M.; Amal, M.; Siti-Zahrah, A.; Zulkafli, A. Control and prevention of Streptococcosis in Cultured Tilapia in Malaysia: A review. Pertanika. J. Trop. Agric. Sci. 2014, 37, 389-410.

38. Ngugi, C.C.; Bowman, J.R.; Omolo, B. A New Guide to Fish Farming in Kenya; Aquaculture Collaborative Research Support Program (ACRSP), Oregon State University: Corvallis, OR, USA, 2007; 95p.

39. Russell, M.; Shuke, R.; Samantha, S. Effects of Conductivity on Survivorship and Weight of Goldfish (Carassius auratus); Juniata College: Huntingdon, PA, USA, 2011.

40. Jeffries, K.M.; Jackson, L.J.; Ikonomou, M.G.; Habibi, H.R. Presence of natural and anthropogenic organic contaminants and potential fish health impacts along two river gradients in Alberta, Canada. Environ. Toxicol. Chem. 2010, 29, 2379-2387. [CrossRef] [PubMed]

41. Elseady, Y.; Zahran, E. Ameliorating effect of $\beta$-carotene on antioxidant response and hematological parameters of mercuric chloride toxicity in Nile tilapia (Oreochromis niloticus). Fish. Physiol. Biochem. 2013, 39, 1031-1041. [CrossRef] [PubMed]

42. Zahran, E.; Risha, E.; Awadin, W.; Palić, D. Acute exposure to chlorpyrifos induces reversible changes in health parameters of Nile tilapia (Oreochromis niloticus). Aquat. Toxicol. 2018, 197, 47-59. [CrossRef] [PubMed]

43. Shayo, S.; Mwita, C.; Hosea, K. Virulence of pseudomonas and aeromonas bacteria recovered from Oreochromis niloticus (perege) from mtera hydropower Dam; Tanzania. Ann. Biol. Res. 2012, 3, 5157-5161.

44. Aly, S.M. A Review of Fish Diseases in the Egyptian Aquaculture Sector: Working Report; WorldFish: Penang, Malaysia, 2013; pp. 1-41.

45. Assefa, A.; Abunna, F. Maintenance of fish health in aquaculture: Review of epidemiological approaches for prevention and control of infectious disease of fish. Veter. Med. Int. 2018, 2018, 1-10. [CrossRef]

46. Harper, C.; Wolf, J.C. Morphologic effects of the stress response in fish. ILAR J. 2009, 50, 387-396. [CrossRef]

47. Abou El-gheit, E. Some Investigations on the role of water parameters in microbial infections of fishes. Egypt. J. Exp. Biol. 2005, 1, 9-14.

48. Austin, B.; Austin, D.A. Bacterial Fish Pathogens; Springer Science and Business Media LLC: Berlin, Germany, 2016.

49. Moustafa, M.; Mohamed, L.A.; Mahmoud, M.; Soliman, W.; El-Gendy, M. Bacterial infections affecting marine fishes in Egypt. J. Am. Sci. 2010, 6, 603-612.

50. Salem, M.; Zahran, E.; Saad, R.; Zaki, V. Prevalence, molecular characterization, virulotyping, and antibiotic resistance of motile aeromonads isolated from Nile tilapia farms at northern Egypt. Mansoura Veter. Med. J. 2020, 21, 56-67. [CrossRef]

51. Hudson, J.A.; De Lacy, K.M. Incidence of motile aeromonads in New Zealand retail foods. J. Food Prot. 1991, 54, 696-703. [CrossRef] 
52. Yucel, N.; Aslim, B.; Beyatli, Y. Prevalence and resistance to antibiotics for Aeromonas species isolated from retail fish in Turkey. J. Food Qual. 2005, 28, 313-324. [CrossRef]

53. Stock, I.; Grüger, T.; Wiedemann, B. Natural antibiotic susceptibility of strains of the Enterobacter cloacae complex. Int. J. Antimicrob. Agents 2001, 18, 537-545. [CrossRef]

54. Matter, A.F.; El Asely, A.M.; Shaheen, A.A.; El-Gawad, E.A.A.; El-Abd, H.; Abbass, A.A. Phenotypic and molecular characterization of bacterial pathogens isolated from diseased freshwater fishes. Int. J. Fish. Aquat. Stud. 2018, 6, 34-41.

55. Cabello, F.C.; Godfrey, H.P.; Tomova, A.; Ivanova, L.; Dölz, H.; Millanao, A.; Buschmann, A.H. Antimicrobial use in aquaculture re-examined: Its relevance to antimicrobial resistance and to animal and human health. Environ. Microbiol. 2013, 15, 1917-1942. [CrossRef] [PubMed]

56. Okocha, R.C.; Olatoye, I.O.; Adedeji, O.B. Food safety impacts of antimicrobial use and their residues in aquaculture. Public Health Rev. 2018, 39, 21. [CrossRef] [PubMed]

57. Ahmed, H.A.; Mohamed, M.E.; Rezk, M.M.; Gharieb, R.M.; Abdel-Maksoud, S.A. Aeromonas hydrophila in Fish and Humans; Prevalence, Virulotyping and Antimicrobial Resistance. Slov. Vet. Res. 2018, 55, 113-124.

58. Ashiru, A. Isolation and antibiotic profile of Aeromonas species from tilapia fish (Tilapia nilotica) and catfish (Clarias betrachus). Pak. J. Nutr. 2011, 10, 982-986. [CrossRef]

59. Popovic, N.T.; Teskeredžić, E.; Strunjak-Perović, I.; Čož-Rakovac, R. Aeromonas hydrophila isolated from wild freshwater fish in Croatia. Veter. Res. Commun. 2000, 24, 371-377. [CrossRef]

60. Castro-Escarpulli, G.; Figueras, M.J.; Aguilera-Arreola, G.; Soler, L.; Fernández-Rendón, E.; Aparicio, G.O.; Guarro, J.; Chacon, M.R. Characterisation of Aeromonas spp. isolated from frozen fish intended for human consumption in Mexico. Int. J. Food Microbiol. 2003, 84, 41-49. [CrossRef]

61. Ramadan, H.; Ibrahim, N.; Samir, M.; El-Moaty, A.A.; Gad, T. Aeromonas hydrophila from marketed mullet (Mugil cephalus) in Egypt: PCR characterization of $\beta$-lactam resistance and virulence genes. J. Appl. Microbiol. 2018, 124, 1629-1637. [CrossRef]

62. Arslan, S.; Küçüksari, R. Phenotypic and genotypic virulence factors and antimicrobial resistance of motile Aeromonas spp. from fish and ground beef. J. Food Saf. 2015, 35, 551-559. [CrossRef]

63. Ye, Y.; Fan, T.; Li, H.; Lu, J.; Jiang, H.; Hu, W.; Jiang, Q. Characterization of Aeromonas hydrophila from hemorrhagic diseased freshwater fishes in Anhui Province, China. Int. Food Res. J. 2013, 20, 1449.

64. Simon, S.S.; Lalitha, K.V.; Joseph, T.C. Virulence properties of Aeromonas spp. from modified-atmosphereand vacuum-packed milk fish (Chanos chanos Forsskal, 1775). Ann. Microbiol. 2016, 66, 1109-1115. [CrossRef]

65. Janda, J.M.; Abbott, S.L. The genus Aeromonas: Taxonomy, pathogenicity, and infection. Clin. Microbiol. Rev. 2010, 23, 35-73. [CrossRef]

66. Odeyemi, O.A.; Ahmad, A. Antibiotic resistance profiling and phenotyping of Aeromonas species isolated from aquatic sources. Saudi J. Biol. Sci. 2015, 24, 65-70. [CrossRef] [PubMed]

67. Citarasu, T.; Dhas, A.; Velmurugan, S.; Viji, T.; Kumaran, T.; Babu, M.M.; Selvaraj, T. Isolation of aeromonas hydrophila from infected ornamental fish hatchery during massive disease outbreak. Int. J. Curr. Res. 2011, 2, 37-41.

68. Sarkar, A.; Saha, M.; Roy, P. Detection of 232bp virulent gene of pathogenic aeromonas hydrophila through PCR based technique: (a rapid molecular diagnostic approach). Adv. Microbiol. 2013, 3, 83-87. [CrossRef]

69. Dar, G.H.; Dar, S.A.; Kamili, A.N.; Chishti, M.Z.; Ahmad, F. Detection and characterization of potentially pathogenic Aeromonas sobria isolated from fish Hypophthalmichthys molitrix (Cypriniformes: Cyprinidae). Microb. Pathog. 2016, 91, 136-140. [CrossRef]

70. Aguilera-Arreola, M.G.; Hernández-Rodríguez, C.; Zúñiga, G.; Figueras, M.J.; Garduño, R.A.; Castro-Escarpulli, G. Virulence potential and genetic diversity of Aeromonas caviae, Aeromonas veronii, and Aeromonas hydrophila clinical isolates from Mexico and Spain: A comparative study. Can. J. Microbiol. 2007, 53, 877-887. [CrossRef]

71. Gonzalez-Serrano, C.; Santos, J.A.; García, M.; Otero, A. irulence markers in Aeromonas hydrophila and Aeromonas veronii biovar sobria isolates from freshwater fish and from a diarrhoea case. J. Appl. Microbiol. 2002, 93, 414-419. [CrossRef]

72. Sha, J.; Kozlova, E.V.; Chopra, A.K. Role of Various enterotoxins in Aeromonas hydrophila-induced gastroenteritis: Generation of enterotoxin gene-deficient mutants and evaluation of their enterotoxic activity. Infect. Immun. 2002, 70, 1924-1935. [CrossRef] [PubMed] 
73. Wang, C.; Cao, X.; Liu, X.; Guo, L.; Hu, T.; Ni, X.; Liu, Y.; Lu, C. Detection of biochemical characters and extracellular proteases in the different isolates of Aeromonas hydrophila. J. Vet. Med. Sci. 2008, 40, 16-19.

74. Hu, M.; Wang, N.; Pan, Z.; Lu, C.; Liu, Y. Identity and virulence properties of Aeromonas isolates from diseased fish, healthy controls and water environment in China. Lett. Appl. Microbiol. 2012, 55, 224-233. [CrossRef] [PubMed]

75. Attia, A.S.; Khedr, M.H.; Zaki, M.S. Occurrence of potentially pathogenic Aeromonas species isolated from raw and ready- to- eat fish marketed in Sharkia Governorate, Egypt. Zagazig Veter. J. 2018, 46, 154-159. [CrossRef]

76. Abd-Elall, A.; Abd-El-Kader, M.; Atia, A.S. Occurrence, seasonal variations and virulence of Aeromonas hydrophila and Aeromonas caviae in fish farms at East Delta, Egypt. Glob. Vet. 2014, 13, 328-336.

77. Singh, V.; Rathore, G.; Kapoor, D.; Mishra, B.N.; Lakra, W.S. Detection of aerolysin gene in Aeromonas hydrophila isolated from fish and pond water. Indian J. Microbiol. 2008, 48, 453-458. [CrossRef]

78. Abd-El-Malek, A.M. Incidence and virulence characteristics of Aeromonas spp. in fish. Veter. World 2017, 10, 34-37. [CrossRef]

79. Younes, A.; Gaafar, A.; Awad, E.S. Virulence determinants and plasmid profile of Aeromonas hydrophila strains isolated from Oreochromis niloticus. Glob. Vet. 2015, 15, 613-617.

80. Al-Fatlawy, H.N.K.; Al-Hadrawy, H. Isolation and characterization of A. hydrophila from the Al-Jadryia river in Baghdad (Iraq). Am. J. Educ. Res. 2014, 2, 658-662. [CrossRef]

81. Hassan, M.A.M.; Noureldin, E.; Mahmoud, M.A.; Fita, N.A. Molecular identification and epizootiology of Aeromonas veronii infection among farmed Oreochromis niloticus in Eastern Province, KSA. Egypt. J. Aquat. Res. 2017, 43, 161-167. [CrossRef]

82. Salem, M.; Zahran, E.; Rawia, S.; Zaki, H.V. Advanced Study on Motile Aeromonas Septicemia (Mas) in Cultured Nile Tilapia (Oreochromis Niloticus). Ph.D. Thesis, Mansoura University, Mansoura, Egypt, 2020.

83. El-Barbary, M.I. Some clinical, microbiological and molecular characteristics of Aeromonas hydrophila isolated from various naturally infected fishes. Aquac. Int. 2010, 18, 943-954. [CrossRef]

(C) 2020 by the authors. Licensee MDPI, Basel, Switzerland. This article is an open access article distributed under the terms and conditions of the Creative Commons Attribution (CC BY) license (http://creativecommons.org/licenses/by/4.0/). 